\author{
건강 관련 요인이 건강기능식품의 이용에 미치는 영향 \\ 최지헌, 유창훈, ${ }^{2}$ 권영대 ${ }^{3}$ \\ ${ }^{1}$ 가톨릭대학교 대학원 보건학과, ${ }^{2}$ 연세대학교 경영연구소 및 경영학과, \\ ${ }^{3}$ 가톨릭대학교 의과대학 인문사회의학과
}

\title{
Effects of Health-related Factors on the Use of Health Functional Foods
}

\author{
Ji-Heon Choi ${ }^{1}$, Chang-Hoon You ${ }^{2}$, Young-Dae Kwon ${ }^{3}$ \\ ${ }^{1}$ Department of Public Health, Graduate School, the Catholic University of Korea, \\ ${ }^{2}$ Yonsei Business Research Institute and School of Business, Yonsei University, \\ ${ }^{3}$ Department of Humanities and Social Medicine, College of Medicine, the Catholic University of Korea
}

\begin{abstract}
$<$ Abstract $>$
Many Koreans have been interested in health functional foods(HHFs). Use of health functional foods is growing rapidly. This study aims to identify the determinants of HFFs use focusing on health related factors. The subjects were 24,626 samples from Korea Health Panel in 2008. The subjects were divided into two group: under the 20 years old and 20 old and over. The logistic regression model was used to examine influence of health-related factors on use of HFFs for each group. About thirty percent of the subjects have used HFFs. The larger family size, higher education level of parents, more stable economic status and chronic diseases were positively related to use more HFFs in younger 20 years old. Higher education level, more stable economic status, chronic diseases were more likely to use HFFs in 20 years of age and over. Health related factors such as disability, chronic diseases, admission, and physician visit affect the use of HFFs in both groups. We confirmed that health related factors as well as socio-demographic and economic factors affect use of HFFs. In-depth knowledge about relationship between health related factors and HFFs is required.
\end{abstract}

Key Words : Determinant, Dietary Supplements, Health Functional Foods, Health Related Factors 


\section{I . 서론}

전 세계적으로 소득 수준이 높아지고 삶의 질에 관심이 많아지면서 건강한 삶을 유지하고 증진시 키기 위한 건강기능식품의 소비가 늘어나고 있다. 건강기능식품의 세계 시장 규모는 2010년에 242억 달러로 추정되며 매년 빠르게 증가하고 있다[1]. 우리나라의 건강기능식품 시장 규모는 연 2조 5천 억원[2]에서 4조원[3][4] 규모로 추정되며 매년 $10 \%$ 이상 성장하고 있다. 우리나라 국민의 건강기능식 품 이용률은 조사대상자와 연구에 따라 다르지만 적게는 $30 \%$ 대에서 많게는 $50 \%$ 대로 보고되어 [4][5][6][7][8][9] 모든 연령대에서 건강기능식품의 이용이 보편화되어 있음을 알 수 있다. 2008년 국 민건강영양조사에서도 최근 1년 이내 2 주 이상 지 속적으로 건강기능식품을 복용한 경험자가 $34.1 \%$ 로 나타났다[10].

과거에 건강기능식품은 건강식품, 건강보조식품, 영양제, 미네랄, 철분제 등 다양한 이름으로 불렸 으며 정의도 모호하여 식품위생법에 의해서 관리 되었다. 2002년 8월에 건강기능식품법이 제정되어 건강기능식품을 효과적으로 관리할 수 있는 체계 를 갖추게 되었다. 건강기능식품의 정의도 관련법 에서 "인체에 유용한 기능성을 가진 원료나 성분 을 이용하여 제조, 가공한 식품"으로 명확하게 정 의하였다.

인체에 유익한 영양소를 공급하여 건강 증진, 질병 예방 등에 도움이 되는 건강기능식품의 긍정 적 기능에도 불구하고[11], 건강기능식품의 이용이 크게 늘면서 특정 영양소 과다 섭취로 인한 영양 소 불균형과 부작용, 정상적 식사를 통한 영양소 섭취 경시, 지나친 기대와 과장 광고, 경제적 부담 등의 문제도 함께 제기되고 있다[8][12][13][14]. 건 강기능식품은 치료 약물과 교차반응을 일으킬 수 있고, 치료에 직간접적인 영향을 미치기 때문에 건 강기능식품의 적절한 선택과 올바른 이용이 필요
하다[15]. 특히 만성 질환자에서 건강기능식품의 복용 양상을 파악하는 것은 중요하다. 이와 같은 건강기능식품 이용과 관련된 문제점을 개선하고 올바른 이용을 유도하기 위해서는 건강기능식품의 이용 양상을 정확히 파악하고, 선택과 이용에 영향 을 미치는 요인을 분석하는 것이 중요하다.

건강기능식품의 이용 양상과 이용에 영향을 미 치는 요인에 관한 연구는 여러 차례 시행되었다. 그러나 대부분이 특정 집단이나 연령대를 대상으 로 한 연구라 결과를 일반화시키기 어렵다는 제한 점을 가지고 있으며, 개인 특성에 따른 이용의 차 이만 보고 이용에 영향을 미치는 요인을 제대로 규명하지 못하였다. 또한 이용에 영향을 미치는 요 인으로 일반적인 인구·경제·사회적 요인을 주로 고 려하고, 건강 관련 요인은 충분히 고려하지 못하였 다. 건강기능식품이 건강에 미치는 영향이 크다는 점을 고려할 때 이의 선택과 이용에 건강 관련 요 인이 어떤 영향을 미치는지 분석하는 것은 중요하 다. 이에 본 연구에서는 전 국민을 대상으로 하여 대표성을 가진 한국의료패널 자료를 활용해서 인 구·사회·경제적 요인과 함께 건강 관련 요인이 건 강기능식품의 이용에 미치는 영향을 분석하고자 하였다.

\section{․ 연구방법}

1. 분석 자료

본 연구는 한국보건사회연구원과 국민건강보험 공단이 수행한 2008년도 한국의료패널(Korea Health Panel) 조사 자료를 활용하였다. 한국의료 패널은 고령화 등으로 인한 급격한 의료비 증가와 관련하여 적정 의료비에 초점을 맞춘 정책 수립과 시행의 기초자료로 활용하기 위한 목적으로 시작 한 패널 조사이다. 전 국민을 대상으로 이 단계 확 
률비례 층화집락 추출법으로 대표 표본가구를 선 정하고, 선정된 가구의 가구원 모두를 조사하였다. 조사 내용은 가구를 대상으로는 가구원 수, 가 구 구성, 소득, 주거 형태, 민간의료보험 가입 등을 조사하고, 가구원 조사에서는 연령, 성, 교육 수준, 직업, 의료보장 유형 등을 조사하였다. 또한, 의약 품, 응급서비스, 입원서비스, 외래서비스, 출산 등 의 의료이용 각 영역별로 이용 횟수, 진료비 등을 조사하였다. 특히 건강기능식품과 관련하여 생활 및 건강증진 의약품 이용, 건강기능식품 복용 여 부, 구매액 등의 자료를 수집하였다.

\section{2. 분석대상자}

한국의료패널 조사에 참여한 전체 조사대상자 7,866 가구, 24,616 명을 연구의 분석 대상자로 선정 하였다. 이 중 건강기능식품 이용 행태가 다르다고 판단되는 의료급여 대상자를 제외한 23,929 명의 자 료를 분석하였다. 건강기능식품 이용의 의사 결정 을 본인이 직접 하기 어려운 20세 미만의 미성년 자 중에서 부모(편부모 포함)와 동거하는 5,240 명 과 20 세 이상의 성인 17,865 명을 본 연구의 최종 분석 대상자로 선정하였다(결측치 제외). 분석은 20세 미만 미성년자와 20세 이상 성인을 구분하여 시행하였다.

\section{3. 주요변수}

건강기능식품 이용 여부는 조사 시점에서 지난 1년 동안 약국에서 구매한 생활/건강증진 관련 의 약품을 3 개월 이상 이용하였거나 건강기능식품 구 매 경험이 있다고 응답한 사람들을 건강기능식품 이용자로 구분하였다. 관련법에 제시된 건강기능식 품의 정의는 "인체에 유용한 기능성을 가진 원료 나 성분을 이용하여 제조, 가공한 식품"이다. 본 연구에서 이용된 건강기능식품은 구입처에 따라
구분하는데, 약국에서 구매한 생활/건강증진관련 의약품은 구체적으로 비타민제, 영양제가 이에 해 당되고, 시장, 마트, 홈쇼핑에서 구매한 건강기능식 품은 인삼가공제품, 홍삼가공제품, 로얄제리제품, 스쿠알렌제품, 클로렐라제춤, 알로에제품, 글루코사 민 함유제품 등이 해당된다.

20세 미만 대상자의 설명변수로 인구·사회적 변 수는 성, 연령(학년), 가구 구성, 가구원 수, 부모의 평균 연령, 부모의 평균 교육 수준, 거주 지역, 국 민건강보험 가입 유형을 포함하였다. 가구원 수는 동거 가구원 수를 조사하였다. 동거 가구원 수는 가족 내의 지지와 부양에 영향을 주고, 이는 건강 기능식품 이용에 영향을 줄 것으로 예상되어 본 연구에 포함하였다. 거주 지역은 행정구역을 기준 으로 서울특별시와 6개 광역시를 대도시로 하고, 그 외의 지역을 중소도시로 분류하였다. 국민건강 보험 가입 유형은 지역과 직장으로 구분하였다. 경 제적 변수는 가구 연간 총소득과 주택 소유 여부 를 고려하였다. 가구 월 평균 소득 대신 가구 연간 총소득으로 조사대상자의 경제적 수준을 측정하였 다. 주택 소유 여부는 자가, 전세, 월세, 기타로 구 분하였다. 건강 관련 변수는 만성 질환 여부, 입원 과 외래 의료서비스 이용 여부를 포함하였다. 6 개 월 이상 질환 보유 시 연령에 관계없이 만성 질환 보유로 간주하였다. 입원과 외래 의료서비스 이용 은 대상자의 건강 상태를 간접적으로 나타내는 지 표로 판단하여 포함시켰다.

20세 이상 대상자의 설명변수로 인구·사회적 변 수는 성, 연령, 결혼 상태, 가구원 수, 교육 수준, 거주 지역, 국민건강보험 가입 유형을 포함하였다. 결혼 상태는 기혼, 이혼과 사별, 미혼으로 구분하 였다. 경제적 변수는 고용 형태, 가구 연간 총소득, 주택 소유 여부를 고려하였다. 고용 형태는 정규 직, 비정규직, 자영업 또는 고용주, 기타로 구분하 였다. 건강 관련 변수는 장애 여부와 만성 질환 여 부, 입원과 외래 의료서비스 이용 여부를 포함하였 
다. 장애 여부는 조사 시점 현재의 장애 여부를 고 려하였다.

\section{4. 분석방법}

연구대상자의 인구·사회적, 경제적 및 건강 관 련 요인에 따라 빈도분석을 실시하였으며, 건강기 능식품 이용 여부의 차이는 $\mathrm{t}$-검정과 카이제곱검정 을 이용하여 분석하였다. 건강기능식품 이용 결정 요인을 분석하기 위하여 로지스틱 회귀분석 (logistic regression)을 사용하였다. 기존 연구와의 비교를 위해 세 가지 모델로 로지스틱 회귀분석을 실시하였다.

첫 번째 모델에서는 건강기능식품 이용에 영향 을 주는 인구·사회적인 요인을 포함하여 분석하였 고, 두 번째 모델에서는 인구·사회적인 요인을 보 정하여 경제적인 요인의 영향을 분석하였으며, 세 번째 모델에서는 인구·사회적 요인과 경제적인 요 인을 보정하여 건강 관련 요인의 영향을 분석하였 다. 통계 분석은 SAS 9.1 버전을 이용하였다.

\section{III. 연구결과}

1. 연구대상자의 일반적 특성과 건강기능식품 이용 현황

1) 20 세 미만의 연령군

한국의료패널 조사대상자 24,616 명에서 의료급 여 대상자를 제외한 23,929 명 중 건강기능식품 이 용자는 모두 7,067명으로 건강기능식품 이용률은 $29.5 \%$ 이었다. <표 1>에 20세 미만의 연구대상자 5,240 명의 특성을 건강기능식품 이용 여부에 따라 제시하였다. 연구대상자 5,240 명 중 건강기능식품 이용자는 1,682 명으로 이용률은 $32.1 \%$ 이었다. 인
구·사회적 요인 중에서 가구 구성, 가구원 수, 부 모의 평균 교육 수준, 국민건강보험 가입 유형은 두 군 간에 통계적으로 유의한 차이를 보였다.

그러나 성별, 연령, 부모의 평균 나이, 거주 지 역 항목은 유의한 차이가 없었다. 경제적 요인에서 는 대상자 가구의 주택 소유 여부와 총 소득이 두 군 간에 유의한 차이가 있었다. 건강 관련 요인에 서는 만성 질환과 외래 의료서비스 이용은 통계적 으로 유의한 차이가 있었지만, 입원 이용은 차이가 없었다.

2) 20 세 이상의 연령군

20 세 이상 성인 대상자 17,865 명 중 건강기능식 품 이용자는 5,151 명으로 이용률은 $28.8 \%$ 이었다 <표 2>. 연구대상자의 평균 나이는 46.5세이며, 건 강기능식품 이용군의 연령이 비이용군보다 적었다. 두 군의 연령대별 분포, 결혼 상태, 교육 수준, 국 민건강보험 가입 유형은 통계적으로 유의한 차이 를 보였다.

경제적 요인에서 고용 형태를 살펴보면, 정규직 $13.5 \%$, 비정규직 $29.4 \%$, 자영업 $26.0 \%$ 로 나타났으 며 두 군 간의 고용 형태는 통계적으로 유의한 차 이가 있었다. 연 평균 가구소득은 3677.6만 원이었 고, 건강기능식품 이용군이 더 높은 소득 수준을 보였으며, 건강기능식품 이용군에서 소득 1 분위의 비율이 높았다. 주택 소유 여부에서도 이용군의 자 가 소유 비율이 더 높아 두 군 간에 유의한 차이 가 있었다. 건강 관련 요인에 있어서 만성 질환의 경우 전체 연구대상자의 $43.6 \%$ 가 있다고 응답하였 으며, 연구대상자의 $4.2 \%$ 는 장애가 있다고 응답하 였다.

연구대상자의 $5.5 \%$ 가 입원 경험이 있었고, 외래 방문 경험은 $65.7 \%$ 가 있다고 응답하였다. 건강 관 련 요인 중 만성 질환과 장애 여부, 외래 의료서비 스 경험에서 두 군 간에 유의한 차이가 있었다. 
<표 1> 건강기능식품 이용에 따른 대상자 특성 - 20세 미만 $(n=5,240)$

단위 : 명, \%

\begin{tabular}{|c|c|c|c|c|c|c|c|}
\hline \multirow{2}{*}{$\overline{\bar{c} \text { 대상자 }}$} & \multicolumn{2}{|c|}{ 전체 } & \multicolumn{2}{|c|}{ 이용자 } & \multicolumn{2}{|c|}{ 비이용자 } & \multirow[t]{2}{*}{$\chi^{2}(p)$ or $t(p)$} \\
\hline & 5,240 & $(100.0)$ & 1,682 & $(32.1)$ & 3,558 & $(67.9)$ & \\
\hline \multicolumn{8}{|l|}{ 성 } \\
\hline 남 & 2,709 & $(51.7)$ & 883 & (52.5) & 1,826 & (51.3) & $0.63(0.426)$ \\
\hline 여 & 2,531 & $(48.3)$ & 779 & $(47.5)$ & 1,732 & $(48.7)$ & \\
\hline 연령(평균士표준편차, 세) & \multicolumn{2}{|r|}{$9.9 \pm 5.4$} & \multicolumn{2}{|r|}{$9.8 \pm 5.2$} & \multicolumn{2}{|r|}{$9.9 \pm 5.4$} & $0.44(0.662)$ \\
\hline \multicolumn{7}{|l|}{ 연령군(학년) } & \multirow{7}{*}{$4.14(0.529)$} \\
\hline 미취학 & 1,552 & (29.6) & 495 & (29.4) & 1,057 & (29.7) & \\
\hline 초등학교 1-3학년 & 894 & (17.1) & 297 & (17.7) & 597 & $(16.8)$ & \\
\hline 초등학교 4-6학년 & 892 & (17.0) & 302 & (17.9) & 590 & (16.6) & \\
\hline 중학생 & 880 & $(16.8)$ & 281 & (16.7) & 599 & (16.8) & \\
\hline 고등학생 & 804 & (15.3) & 245 & (14.6) & 559 & (15.7) & \\
\hline 대학생 & 218 & ( 4.2) & 62 & ( 3.7$)$ & 156 & ( 4.4) & \\
\hline \multicolumn{7}{|l|}{ 가족 구성 } & \multirow{4}{*}{$8.41(0.015)$} \\
\hline 부모+자녀 & 5,105 & (97.4) & 1,652 & (98.2) & 3,453 & $(97.0)$ & \\
\hline 편부+자녀 & 44 & $(0.8)$ & 6 & $(0.4)$ & 38 & (1.1) & \\
\hline 편모+자녀 & 91 & ( 1.7$)$ & 24 & ( 1.4$)$ & 67 & ( 1.9) & \\
\hline 가구원 수(평균士표준편차, 명) & \multicolumn{2}{|r|}{$4.1 \pm 0.7$} & \multicolumn{2}{|c|}{$4.0 \pm 0.6$} & \multicolumn{2}{|r|}{$4.1 \pm 0.7$} & $3.53(0.000)$ \\
\hline 부모 연령(평균士표준편차, 세) & \multirow{2}{*}{\multicolumn{2}{|c|}{$\begin{array}{r}40.5 \pm 24.1 \\
13.6 \pm 2.4\end{array}$}} & \multicolumn{2}{|c|}{$41.1 \pm 34.2$} & \multicolumn{2}{|c|}{$40.3 \pm 17.4$} & $-0.94(0.349)$ \\
\hline 부모 교육수준(평균표푼편차, 년) & & & & $4.1 \pm 2.2$ & & $13.3 \pm 2.5$ & $-11.10(0.000)$ \\
\hline \multicolumn{8}{|l|}{ 국민건강보험 가입 유형 } \\
\hline 직장 가입자 & 3,340 & (63.7) & 1,157 & $(68.8)$ & 2,183 & $(61.4)$ & \multirow[t]{2}{*}{$27.30(0.000)$} \\
\hline 지역 가입자 & 1,900 & $(36.3)$ & 525 & $(31.2)$ & 1,375 & (38.6) & \\
\hline \multicolumn{7}{|l|}{ 주택 소유 } & \multirow{5}{*}{$38.14(0.000)$} \\
\hline 자가 & 3,188 & $(60.8)$ & 1,108 & $(65.9)$ & 2,080 & (58.5) & \\
\hline 전세 & 1,264 & (24.1) & 387 & (23.0) & 877 & (24.6) & \\
\hline 월세 & 579 & (11.1) & 131 & ( 7.8) & 448 & (12.6) & \\
\hline 기타 & 209 & $(4.0)$ & 56 & ( 3.3$)$ & 153 & ( 4.3) & \\
\hline 연간 가구소득(평균 \pm 표준편차, 만 원) & 4,086 & $2,347.6$ & $4,704.7 \pm$ & $2,533.4$ & 3,794 . & $\pm 2,194.7$ & $-12.66(0.000)$ \\
\hline 1분위 & 1,428 & (27.3) & 625 & (37.2) & 803 & (22.5) & \\
\hline 2분위 & 1,300 & (24.8) & 490 & (29.1) & 810 & (22.8) & \\
\hline 3분위 & 1,219 & (23.3) & 326 & (19.4) & 893 & (25.1) & $231.39(0.000)$ \\
\hline 4분위 & 1,293 & $(24.6)$ & 241 & $(14.3)$ & 1,052 & $(29.6)$ & \\
\hline 거주 지역 & & & & & & & \\
\hline 대도시 & 2,327 & (44.4) & 773 & $(46.0)$ & 1,554 & (43.7) & $2.41(0.121)$ \\
\hline 중소도시 & 2,913 & (55.6) & 909 & $(54.0)$ & 2,004 & (56.3) & \\
\hline 만성질환 & & & & & & & \\
\hline 유 & 935 & (17.8) & 351 & (20.9) & 584 & (16.4) & $15.46(0.000)$ \\
\hline 무 & 4,350 & (82.2) & 1,331 & (79.1) & 2,974 & (83.6) & \\
\hline 입원이용 & & & & & & & \\
\hline 유 & 215 & ( 4.1) & 67 & ( 4.0) & 148 & ( 4.2) & $0.090(0.764)$ \\
\hline 무 & 5,025 & (95.9) & 1,615 & $(96.0)$ & 3,410 & (95.8) & \\
\hline 외래이용 & & & & & & & \\
\hline 유 & 4,032 & (77.0) & 1,380 & (82.1) & 2,652 & (74.5) & $36.30(0.000)$ \\
\hline 무 & 1,208 & (23.0) & 302 & (17.9) & 906 & (25.5) & \\
\hline
\end{tabular}


<표 2> 건강기능식품 이용에 따른 대상자 특성 - 20세 이상 $(n=17,865)$

단위 : 명, \%

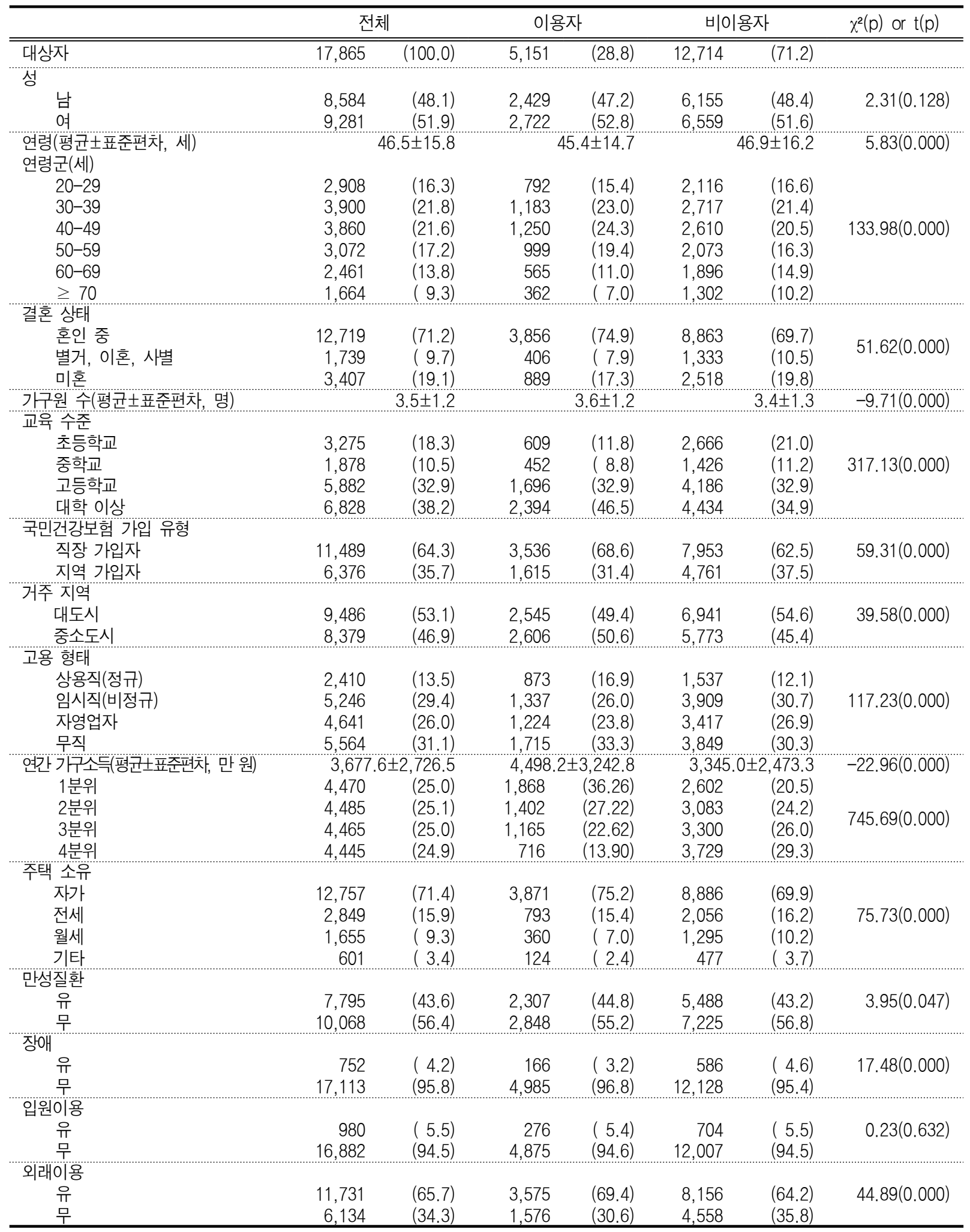


2. 건강기능식품 이용에 영향을 미치는 요인

로지스틱 회귀분석으로 건강기능식품 이용에 영 향을 주는 요인을 분석하였다. 20세 미만과 20세 이상 연령군 모두 회귀분석 모형은 세 가지 형태 로 구분하여 분석하였다.

\section{1) 20 세 미만의 연령군}

첫 번째 모형은 성, 연령, 가구 구성, 부모의 연 령, 부모의 교육 수준 같은 인구·사회적 요인이 건 강기능식품 이용에 미치는 영향을 알아보았다. 미 성년자 본인의 나이(학력)가 증가할수록, 가구 구 조에서 편부의 경우, 가구원 수가 증가할수록 건강 기능식품을 이용하지 않는 것으로 나타났다.

두 번째 모형에서는 인구·사회적 요인을 통제하 고, 경제적 요인들이 건강기능식품 이용 여부에 미 치는 영향을 살펴보았다. 가구 소득이 증가할수록 건강기능식품을 많이 이용하였고, 주택 소유 여부 에서는 자가 소유에 비해서 전세, 월세인 경우 건 강기능식품을 적게 이용하는 것으로 나타났다.

세 번째 모형에서는 인구·사회적 요인과 경제적 요인을 통제하고, 건강 관련 요인이 건강기능식품 이용에 미치는 영향을 살펴보았다. 만성 질환이 있 는 사람과 외래 의료서비스 이용 경험이 있는 사 람이 통계적으로 유의하게 건강기능식품을 더 많 이 이용하는 것으로 나타났다. 입원 경험이 있는 사람이 건강기능식품을 적게 이용하였으나 통계적 으로 유의하지는 않았다.

\section{2) 20 세 이상의 연령군}

첫 번째 모형은 성, 연령, 결혼 상태, 교육 수준, 가구원 수, 거주 지역을 포함한 인구·사회적 요인 을 분석하였다. 여성이 남성보다 건강기능식품을 적게 이용하였고, 40 대 이상 연령층에서 20대보다
더 많이 이용하는 것으로 나타났다. 특히 50 대가 건강기능식품을 가장 많이 이용하는 것으로 나타 났다. 결혼 상태에서는 현재 결혼을 유지하고 있는 사람에 비해 사별 또는 이혼한 사람이 건강기능식 품을 더 많이 이용하는 것으로 나타났지만 통계적 으로 유의하지는 않았다. 반면에 미혼인 사람은 건 강기능식품을 더 적게 이용하는 것으로 나타났다. 교육 수준이 높을수록 건강기능식품의 이용이 증 가하는 것으로 나타났다. 대도시 거주자는 그 이외 의 지역 거주자보다 건강기능식품을 더 많이 이용 하였다.

두 번째 모형에서는 인구·사회적 요인을 통제하 고, 경제적 요인이 건강기능식품 이용에 미치는 영 향을 살펴보았다. 고용 형태는 유의하지 않았으며, 가구 소득이 증가할수록 건강기능식품을 많이 이 용하였다. 주택 소유 여부에서는 자가 소유에 비해 서 전세, 월세인 경우 건강기능식품을 적게 이용하 는 것으로 나타났다.

세 번째 모형에서는 인구·사회적 요인과 경제적 요인을 통제하고, 건강 관련 요인이 건강기능식품 이용에 미치는 영향을 살펴보았다. 만성 질환이 있 는 사람과 외래 의료서비스 이용 경험이 있는 사 람이 없는 사람에 비해 건강기능식품을 더 많이 이용하는 것으로 나타났으며 이는 통계적으로 유 의하였다. 장애가 있는 사람과 입원 경험이 있는 사람이 건강기능식품을 적게 이용하였으나 통계적 으로 유의하지는 않았다. 
<표 3> 건강기능식품 이용에 대한 로지스틱 회귀분석 - 20세 미만 $(n=5,240)$

\begin{tabular}{|c|c|c|c|}
\hline & 모형 1 & 모형 2 & 모형 3 \\
\hline & Odds ratio $(95 \% \mathrm{Cl})$ & Odds ratio $(95 \% \mathrm{Cl})$ & Odds ratio $(95 \% \mathrm{Cl})$ \\
\hline \multicolumn{4}{|l|}{ 성 } \\
\hline 남 & 1 & 1 & 1 \\
\hline 여 & $1.024(0.910-1.152)$ & $0.999(0.887-1.126)$ & $0.997(0.885-1.125)$ \\
\hline 연령 & $1.010(0.998-1.023)$ & $0.998(0.986-1.011)$ & $1.008(0.995-1.022)$ \\
\hline \multicolumn{4}{|l|}{ 가족 구성 } \\
\hline 부모+자녀 & 1 & 1 & 1 \\
\hline 편부+자녀 & $0.374(0.155-0.903)$ & $0.458(0.187-1.117)$ & $0.481(0.196-1.181)$ \\
\hline 편모+자녀 & $0.717(0.438-1.176)$ & $1.168(0.700-1.943)$ & $1.229(0.737-2.051)$ \\
\hline 가구원 수 & $0.857(0.779-0.942)$ & $0.853(0.774-0.941)$ & $0.864(0.783-0.954)$ \\
\hline 부모 연령 & $1.004(0.997-1.012)$ & $1.004(0.999-1.010)$ & $1.004(0.999-0.010)$ \\
\hline 부모 학력 & $1.140(1.111-1.170)$ & $1.075(1.045-1.107)$ & $1.073(1.042-1.104)$ \\
\hline \multicolumn{4}{|l|}{ 거주 지역 } \\
\hline 대도시 & 1 & 1 & 1 \\
\hline 중소도시 & $1.025(0.910-1.154)$ & $1.051(0.931-1.186)$ & $1.052(0.932-1.188)$ \\
\hline 연간 가구소득 $(\mathrm{log})$ & & $1.794(1.574-2.045)$ & $1.783(1.564-2.032)$ \\
\hline \multicolumn{4}{|l|}{ 주택 소유 } \\
\hline 자가 & & 1 & 1 \\
\hline 전세 & & $0.856(0.740-0.991)$ & $0.863(0.745-0.999)$ \\
\hline 월세 & & $0.740(0.595-0.920)$ & $0.750(0.603-0.933)$ \\
\hline 기타 & & $0.921(0.665-1.276)$ & $0.923(0.666-1.281)$ \\
\hline \multicolumn{4}{|l|}{ 만성질환 } \\
\hline 무 & & & 1 \\
\hline 유 & & & $1.220(1.044-1.424)$ \\
\hline \multicolumn{4}{|l|}{ 입원이용 } \\
\hline 무 & & & 1 \\
\hline 유 & & & $0.949(0.689-1.290)$ \\
\hline \multicolumn{4}{|l|}{ 외래이용 } \\
\hline 무 & & & 1 \\
\hline 유 & & & $1.454(1.233-1.715)$ \\
\hline N & 5,239 & 5,239 & 5,239 \\
\hline$-2 \log L$ & 6,442 & 6,323 & 6,290 \\
\hline Wald test & $124.73(0.000)$ & $220.73(0.000)$ & $248.51(0.000)$ \\
\hline
\end{tabular}

약어: 신뢰구간, $\mathrm{Cl}$

주) 미성년자의 연령과 학년은 상관성이 매우 높아 다중공선성이 발생하므로 분석모형에서 학년은 제외함 모형 1: 건강기능식품 이용에 영향을 주는 인구·사회적인 요인을 포함하여 분석

모형 2: 인구·사회적인 요인을 보정하여 경제적인 요인의 영향을 분석

모형 3: 인구·사회적 요인과 경제적인 요인을 보정하여 건강 관련 요인의 영향을 분석 
<표 4> 건강기능식품 이용에 대한 로지스틱 회귀분석 - 20세 이상 $(\mathrm{n}=17,865)$

\begin{tabular}{|c|c|c|c|}
\hline & $\begin{array}{c}\text { 모형 } 1 \\
\text { Odds ratio }(95 \% \mathrm{Cl}) \\
\end{array}$ & $\begin{array}{c}\text { 모형 2 } \\
\text { Odds ratio }(95 \% \mathrm{Cl}) \\
\end{array}$ & $\begin{array}{c}\text { 모형 } 3 \\
\text { Odds ratio }(95 \% \mathrm{Cl}) \\
\end{array}$ \\
\hline \multicolumn{4}{|r|}{ 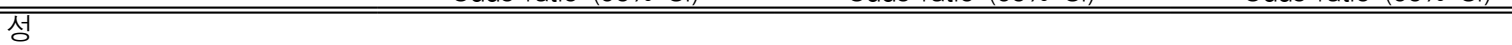 } \\
\hline 남 & 1 & 1 & 1 \\
\hline 여 & $0.823(0.769-0.882)$ & $0.888(0.824-0.958)$ & $0.939(0.869-1.015)$ \\
\hline \multicolumn{4}{|l|}{ 연령(세) } \\
\hline $20-29$ & 1 & 1 & 1 \\
\hline 30-39 & $1.074(0.933-1.237)$ & $1.106(0.957-1.277)$ & $1.108(0.959-1.280)$ \\
\hline $40-49$ & $1.276(1.093-1.489)$ & $1.264(1.077-1.482)$ & $1.230(1.047-1.444)$ \\
\hline $50-59$ & $1.749(1.478-2.069)$ & $1.542(1.295-1.835)$ & $1.415(1.185-1.690)$ \\
\hline $60-69$ & $1.366(1.134-1.646)$ & $1.332(1.098-1.616)$ & $1.165(0.955-1.420)$ \\
\hline$\geq 70$ & $1.426(1.158-1.755)$ & $1.528(1.230-1.897)$ & $1.308(1.048-1.634)$ \\
\hline \multicolumn{4}{|l|}{ 결혼 상태 } \\
\hline 혼인 중 & 1 & 1 & 1 \\
\hline 별거, 이혼, 사별 & $1.019(0.893-1.163)$ & $1.146(1.001-1.312)$ & $1.167(1.019-1.337)$ \\
\hline 미혼 & $0.724(0.633-0.828)$ & $0.727(0.632-0.835)$ & $0.782(0.679-0.900)$ \\
\hline \multicolumn{4}{|l|}{ 교육 수춘 } \\
\hline 초등학교 & 1 & 1 & 1 \\
\hline 중학교 & $1.369(1.183-1.584)$ & $1.290(1.113-1.496)$ & $1.278(1.102-1.482)$ \\
\hline 고등학교 & $2.022(1.781-2.297)$ & $1.762(1.546-2.007)$ & $1.785(1.566-2.034)$ \\
\hline 대학 이상 & $3.268(2.855-3.742)$ & $2.401(2.081-2.770)$ & $2.468(2.138-2.850)$ \\
\hline 가구원 수 & $1.082(1.051-1.114)$ & $0.975(0.944-1.007)$ & $0.985(0.954-1.018)$ \\
\hline \multicolumn{4}{|l|}{ 거추 지역 } \\
\hline 대도시 & 1 & 1 & 1 \\
\hline 중소도시 & $1.133(1.060-1.211)$ & $1.106(1.034-1.183)$ & $1.109(1.036-1.187)$ \\
\hline \multicolumn{4}{|l|}{ 고용 형태 } \\
\hline 상용직(정규) & & 1 & 1 \\
\hline 임시직(비정규) & & $0.905(0.809-1.012)$ & $0.916(0.819-1.026)$ \\
\hline 자영업자 & & $0.982(0.874-1.102)$ & $0.987(0.879-1.109)$ \\
\hline 무직 & & $1.121(0.998-1.260)$ & $1.123(0.999-1.262)$ \\
\hline 연간 가구소득(log) & & $1.573(1.486-1.665)$ & $1.567(1.480-1.659)$ \\
\hline \multicolumn{4}{|l|}{ 추택 소유 } \\
\hline 자가 & & 1 & 1 \\
\hline 전세 & & $0.825(0.750-0.908)$ & $0.828(0.752-0.911)$ \\
\hline 월세 & & $0.742(0.654-0.843)$ & $0.747(0.657-0.848)$ \\
\hline 기타 & & $0.726(0.590-0.893)$ & $0.729(0.592-0.898)$ \\
\hline \multicolumn{4}{|l|}{ 창애 } \\
\hline 무 & & & 1 \\
\hline 유 & & & $0.927(0.771-1.115)$ \\
\hline \multicolumn{4}{|l|}{ 만성칠환 } \\
\hline 무 & & & 1 \\
\hline 유 & & & $1.209(1.108-1.318)$ \\
\hline \multicolumn{4}{|l|}{ 입원이용 } \\
\hline 무 & & & 1 \\
\hline 유 & & & $0.925(0.796-1.075)$ \\
\hline \multicolumn{4}{|l|}{ 외래이용 } \\
\hline 무 & & & 1 \\
\hline 유 & & & $1.274(1.169-1.388)$ \\
\hline $\mathrm{N}$ & 17,865 & 17,865 & 17,860 \\
\hline$-2 \log L$ & 20,865 & 20,488 & 20,401 \\
\hline Wald test & $566.99(0.000)$ & $870.92(0.000)$ & $942.8387(0.000)$ \\
\hline $\begin{array}{l}\text { 약어: 신뢰구간, } \mathrm{Cl} \\
\text { 모형 } 1: \text { 건강기능식품 } \\
\text { 모형 2: 인구·사회적은 }\end{array}$ & 정하여 경제적인 요인 & 을 포함하여 분석 & \\
\hline
\end{tabular}




\section{IV. 결론 및 제언}

본 연구는 연구방법 측면에서 선행 연구와 차별 성을 가지고 있다. 우선, 연구대상자가 전 국민을 대표할 수 있는 자료를 활용하여 분석했다는 점에 서 차이가 있다. 기존 연구는 대부분 특정 지역 주 민 또는 일부 연령대를 대상으로 편의표본을 추출 하였기 때문에 지역이나 대상자의 특성에 따라 건 강기능식품의 이용률이나 이용 요인에 상당한 차 이가 있었다[5][6][7][9][16][17][18][19]. 따라서 연구 결과를 전체 대상자에 대해 직접적으로 일반화하 기가 어렵다.

본 연구에서는 분석 대상자를 20 세 미만과 20세 이상의 두 집단으로 구분하여 이용 여부와 이용에 영향을 미치는 요인을 조사하였다. 대상을 두 개의 집단으로 구분한 이유는 어린이와 청소년은 성인 과 다르게 건강기능식품 구입 동기나 욕구가 약하 고 구매력이 낮기 때문이다. 또한 이들은 건강기능 식품에 대한 정보나 관심이 제한적이다. 초등학생 을 대상으로 건강기능식품 섭취를 조사한 선행 연 구에서 부모의 학력수준, 가구 월평균 수입, 가정 의 사회경제적 수준이 섭취와 관련성이 높았는데 [7], 이는 초등학생의 건강기능식품 이용에 본인보 다 부모의 영향이 더 크게 작용함을 의미한다. 청 소년을 대상으로 한 연구에서도 건강기능식품의 섭취 계기는 '부모님의 권유'라고 응답한 사람이 $71.9 \%$ 로 '스스로 결정' $(16.3 \%)$ 보다 월등히 많았고, 정보 습득 경로도 '부모님의 설명'이 $50.5 \%$ 로 가장 많았다[19]. 청소년[5]과 대학생[18]을 대상으로 한 다른 연구에서도 비슷한 결과를 보였다. 20세 미만 미성년자의 경우 건강기능식품 선택에 본인의 특 성보다는 부모나 가족의 특성이 더 영향을 미치는 것으로 보인다. 이에 전체 대상자를 두 개의 군으 로 구분하고, 20 세 미만에서는 부모나 가족의 특성 을 나타내는 설명변수를 포함하여 분석하였다.

기존 연구에서는 주로 건강기능식품을 식품 소
비의 관점에서 접근하여 이용자의 연령이나 교육 수준, 소득 등 개인의 인구·사회경제적 특성 위주 로 건강기능식품의 이용 요인을 분석하였다. 건강 기능식품이 가지고 있는 기능 향상의 특성이나 이 용 동기를 고려하였을 때, 건강 상태와 같은 건강 관련 요인은 연령이나 교육 수준보다도 건강기능 식품 이용에 더 직접적인 영향을 미치리라 추정된 다. 그러나 상당수의 선행 연구에서는 건강 관련 요인을 적절하게 고려하지 못하여 분석결과에 편 이(bias)가 발생할 가능성이 있다. 본 연구에서는 건강 관련 요인을 중요한 요인으로 부각시켜 분석 모형을 구축하였고, 실제 분석 결과도 건강 관련 요인이 건강기능식품 이용에 영향을 미치는 중요 한 요인임을 보여주었다. 향후 건강기능식품의 이 용 요인을 파악하는 연구에서 건강관련 요인은 반 드시 포함되어야 할 것으로 생각된다.

본 연구의 건강기능식품 이용률은 $29.5 \%$ 로 선행 연구보다 다소 낮았다. 이는 연구대상자와 건강기 능식품 섭취(이용)의 기준에 차이가 있어서 나타난 결과로 보인다. 기존의 연구는 대부분 특정 지역 거주자나 특정 연령대의 편의표집에 의해 대상자 를 선정하였다. 본 연구의 이용률은 전체 인구를 대상으로 한 국민건강영양조사의 결과와는 비슷하 였다. 이용 기준에서는 건강기능식품 시음행사 등 의 일시적인 이용을 포함하거나 마늘진액 등을 건 강기능식품에 포함하는 등 완화된 기준을 적용한 선행 연구가 많았다. 본 연구에서는 건강기능식품 의 정의를 기능성이 확인된 제품군으로 한정하였 고, 건강기능식품 이용 기준을 약국에서 구매하고 3 개월 이상 복용하거나 마트, 홈쇼핑, 건강기능식 품 전문점 등에서의 구매 경험을 이용으로 간주하 였다.

20세 미만 대상자에서 부모의 교육기간이 길수 록 대상자의 건강기능식품 이용 가능성이 높았다. 이는 초등학생을 대상으로 한 연구에서 건강기능 식품 섭취군의 부모 학력이 더 높았던[7] 결과와 
동일하였다. 기존 연구와 다르게 분석모형에 가구 구성을 포함시켜 분석하였는데, 편부와 같이 사는 대상자는 양부모 또는 편모와 사는 대상자보다 건 강기능식품 이용 가능성이 낮았다. 아버지보다 어 머니가 자녀의 건강기능식품 이용에 더 영향을 미 치는 것으로 보인다. 이는 가족 구성원의 건강관리 에서 주부나 어머니가 중요한 역할을 한다[20]는 기존 연구의 결과와 같은 맥락으로 해석할 수 있 다.

20세 이상 대상자에서 여성이 남성보다 건강기 능식품 이용을 적게 하는 것으로 나타났으나, 이전 연구에서는 성별에 따라 차이가 없거나[6] 여성이 많이 섭취한다고 하여[15][21][22] 차이를 보였다. 성별 차이와 영향에 대해서는 추가 연구가 필요하 다고 생각된다. 연령이 증가할수록 건강기능식품 이용의 가능성이 높아지는데, 50 대에서 가장 높고 60 대 이상에서는 감소하는 것으로 나타났다. 이와 관련하여 45-59세가 건강기능식품 이용에서 가장 긍정적인 경험을 가지고 있는 반면, 60 세 이상은 건강기능식품에 대한 인식이 부정적이라는 조사 결과가 있다[23]. 이는 단순히 연령의 증가에 따라 일관성 있는 경향을 보이는 것이 아니라 연령대별 로 건강기능식품의 선호와 이용에 차이가 있음을 의미하므로 역시 추가 연구가 필요할 것으로 보인 다. 사회경제적 요인 중에서는 선행 연구와 마찬가 지로 교육 수준과 소득[6][15][24]이 유의한 요인이 었다. 특히 교육 수준은 종류와 관계없이 식이보충 제(dietary supplement) 이용을 증가시키는 유의한 요인으로 보고되었는데[24], 건강기능식품을 포괄 적으로 정의한 본 연구에서도 교육 수준은 동일한 결과를 보였다.

건강 관련 요인에서는 만성 질환이 있는 경우와 외래이용 경험이 있는 경우에 건강기능식품을 이 용할 확률이 높았다. 반면, 장애와 입원 경험은 건 강기능식품 이용과 연관성이 없었다. 선천적 또는 후천적인 장애는 건강기능식품의 이용과 관련성이
없으며, 만성 질환이 있는 경우 건강기능식품 이용 가능성이 높다는 선행 연구 결과[15]와 일치하였 다. 외래와 입원진료 경험의 차이는 건강 상태와 건강기능식품 이용의 동기나 목적과 관련이 있는 것으로 보인다. 외래진료의 경우 중증도가 낮거나 만성 질환의 일상적 관리를 목적으로 하는 환자가 많다. 건강기능식품은 치료제가 아니고 만성 질환 이나 경증 질환의 완화나 기능 개선, 질병 예방을 위해 이용하므로 외래진료를 받는 대상자와는 관 련성이 높으나 중증도가 높은 입원진료를 받는 대 상자와는 관련성이 떨어질 수밖에 없다.

이 연구는 몇 가지 제한점을 가지고 있다. 건강 기능식품의 선택과 이용은 객관적인 건강 상태와 관련이 있을 뿐만 아니라 주관적 건강 상태 평가, 흡연·음주·운동 등 건강행태와 상호작용이 있을 수 있지만, 본 연구에서는 자료의 제약으로 인해 분석 모형에 이를 포함시키지 못했다. 선행 연구에 따르 면 음주 빈도, 흡연 여부, 건강 관심도, 자아 건강 평가는 대상자의 건강기능식품 섭취에 영향을 미 치지 않았다는 보고[9]가 있지만, 건강에 대한 관 심과 건강기능식품에 대한 지식 수준이 높은 대상 자가 섭취율이 더 높고[6], 다양한 종류의 건강기 능식품을 섭취하는 것으로[8] 보고되어 향후 연구 에서 추가적인 분석이 요구된다. 그 외에 식품산업 과 기술에 대한 신뢰도, 건강기능식품에 대한 인식 등의 심리적 요인도 고려할[23][25] 필요가 있을 것 으로 보인다. 본 연구에서는 건강기능식품의 이용 여부만을 분석하였으나 건강기능식품의 이용에 드 는 경제적 부담(비용)을 분석하면 요인별 차이를 더 분명하게 볼 수 있을 것으로 생각된다.

본 연구는 우리나라 전 국민을 대표할 수 있는 표본자료를 활용하여 건강기능식품의 이용률과 이 용요인을 분석하였다는 점에서 의의가 있다. 또한 건강기능식품의 이용을 식품 소비의 관점에서 보 던 것에다 건강 관련 요인을 포함하여 분석모형을 정교화 하였다. 건강기능식품 이용에 영향을 미치 
는 요인을 인구·사회적, 경제적, 건강 관련 요인의 3 개 모형으로 나누어 다변량 분석을 수행함으로써 변수 간 상호요인을 통제한 후 건강 관련 요인이 건강기능식품 이용에 미치는 영향을 분석하였다. 이를 통해 인구·사회적 요인과 경제적 요인이 건 강기능식품 이용에 영향을 미친다는 것을 다시 확 인하였고, 객관적으로 건강 문제를 가지고 있는 경 우에 건강기능식품의 이용 확률이 높아짐을 확인 하였다. 이를 계기로 건강 관련 요인이 건강기능식 품의 이용에 미치는 영향을 보다 구체적으로 파악 할 필요성을 제기하였다.

\section{참고문헌}

1. Leatherhead Food Research. Future directions for the global functional foods market, http://www. leatherheadfood.com/long-may-the-growth-in-func tional-foods-continue.

2. 문상덕(2009), 건강기능식품법의 현황과 과제, 법 과 정책연구, Vol.9(1);49-80.

3. Hwang, J.S., Kim, S.J., Kim, H.B.(2009), Development and industry of health functional food in Korea, Food Science and Technology Research, Vol.15;1-4.

4. 김효정, 김미라(2009), 노인들의 건강식품 섭취의 도에 영향을 미치는 인구통계학적 특성 및 사회, 심리적 요인에 관한 연구, 한국생활과학회지, Vol.18(1);201-210.

5. 김선효, 한지혜, 황유진, 김화영(2005), 우리나라 일부 청소년의 건강기능식품 섭취 실태, 한국영양 학회지, Vol.38(10);864-872.

6. 김선효, 한지혜, 김화영(2010), 우리나라 중년기의 건강기능식품 섭취에 영향을 미치는 요인에 관한 연구, Vol.43(3);294-303.

7. 김선효, 한지혜, 김화영(2010), 우리나라 일부 초등 학생의 건강기능식품 섭취 실태, 한국영양학회지,
Vol.43(2);161-170.

8. 정혜경, 이해영(2011), 우리나라 일부지역 연령대 별 건강기능식품 이용 실태, 대한영양사협회 학술 지, Vol.17(2);190-205.

9. 김선효(2011), 우리나라 노년기의 건강기능식품 섭 취 실태 및 관련 요인 조사, 한국식생활문화학회 지, Vol.26(1);30-38.

10. 보건복지부·질병관리본부(2009), 2008 국민건강통 계-국민건강영양조사 제 4 기 2 차년도, 보건복지부, p.392.

11. Williamson, C.(2009), Functional foods: what are the benefits? British Journal of Community Nursing, Vol.14;230-236.

12. 구난숙, 박지연(2001), 대전지역 성인 남녀의 건 강보조제 및 건강식품 섭취 실태, 한국생활과학회 지, Vol.10(2);205-213.

13. 이희섭, 이혜숙, 이정애, 강금지(2001), 춘천지역 60세 이상 노년층의 건강식품 섭취실태 조사, 대 한지역사회영양학회지, Vol.6(4);635-644.

14. Hu, F.B.(2011), Do functional foods have a role in the prevention of cardiovascular disease? Circulation, Vol.124;538-540.

15. 이훈호, 박현아, 강재헌, 강주호, 김경우, 조영규, 송혜령, 이정선(2009), 한국인은 어떤 식이보충제 를 복용하고 있는가? -2005년 국민건강영양조사를 중심으로-, 가정의학회지, Vol.30(12);934-943.

16. 김은영, 류기상, 허영란(2007), 광주 지역 성인의 기능성 식품의 섭취 및 구입에 영향을 미치는 요 인, 대한지역사회영향학회지, Vol.12(6);782-789.

17. 박진선, 이준호(2008), 대전지역 학령기 아동의 건강기능식품 섭취실태 및 부모의 요구도, 대한지 역사회영양학회지, Vol.13(4);463-475.

18. 김선효(2010), 우리나라 일부 대학생의 건강기능 식품 섭취 실태 및 섭취 요인 연구, 한국식생활문 화학회지, Vol.25(2);150-159.

19. 김지혜, 주지형(2011), 청주·청원 지역 일부 청소 년의 기능성 식품 섭취 실태 및 관련 교육에 대 한 태도, 대한가정학회지, Vol.49(6);95-107. 
20. 최지숙, 김기진(2003), 아동비만과 어머니의 생활 습관 및 건강신념의 관련성, 발육발달, Vol.11(3);57-72.

21. Kim, S.H., Keen, C.L.(1999), Patterns of vitamin and mineral supplement usage by adolescents attending athletic high schools in Korea, Int. J. Sport Nutr, Vol.9(4);391-405.

22. 김윤정, 문주애, 민혜선(2004), 중년기의 비타민 무기질 보충제 사용과 건강관련 생활습관 조사, 대한지역사회영양학회지, Vol.9(3);303-314.

23. Niva, M., Mäkelä, L.(2007), Finns and functional foods: socio-demographics, health efforts, notions of technology and the acceptability of health-promoting foods, International Journal of Consumer Studies, Vol.31;34-45.

24. Ock, S.M., Hwang, S.S., Lee, J.S., Song, C.H., Ock, C.M.(2010), Dietary supplement use by South Korean adults: data from the national complementary and alternative medicine use survey (NCAMUS) in 2006, Nutrition Research and Practice, Vol.4(1);69-74.

25. 황성완(2011), 광고 심의 결과로 본 건강기능식품 광고 특성, 보건의료산업학회지, Vol.5(2);15-22. 